\title{
Law Enforcement on Merger of Indemnity Claims in Criminal Case Persecution
}

\section{Edi Sutomo*)}

*) Student of Masters (S2) of Law Faculty of Law Unissula and Prosecutors at the Sampang District Attorney, email edysutomo82@gmail.com

\begin{abstract}
The purpose of this study is to analyze and explain: the causes of the Crime of Persecution; Implementation of Law Enforcement on the Merger of Indemnity Claims in the Criminal Case of Persecution, the factors that hinder the implementation of the Law Enforcement, as well as the efforts made in overcoming the obstacles in the Merger of Indemnity Claims in the Criminal Case of Persecution at the Sampang District Court in the future. This type of research is normative legal research supported by empirical legal research, and uses a statutory approach as primary legal material. The results showed that the causes of the crime of persecution in Sampang Regency were: alcohol and psychological factors. Implementation of Law Enforcement on the Merger of Indemnity Claims in the Criminal Case of Persecution at the Sampang District Court, it is known that the defendant has been tried with criminal sanctions, but does not include compensation for victims of criminal acts of persecution. Obstacles or barriers to the implementation of law enforcement on the merger of indemnity suit in the case of criminal offense at the Sampang District Court are: the legal factor itself; law enforcement factors; factor of means or facilities that support law enforcement; community factors; cultural factors.

Keywords: Enforcement, Crime, Persecution, Compensation; Claims.
\end{abstract}

\section{Introduction}

The state of Indonesia is a state of law (rechtsstaat) where law basically aims to achieve peace in living together, which is harmony between order and peace. ${ }^{1}$ This is implied in the preamble of paragraph IV of the 1945 Constitution, which states that the aim of the Indonesian state is to protect the entire Indonesian nation and all Indonesian blood, promote public welfare, educate the nation's life, and participate in implementing world order.

Until now, crime is increasingly rampant, for example the Crime of Persecution, therefore it is necessary to overcome efforts, in general this can be done in two ways, namely penal and non-penal. Actions taken after a crime occurs and non-penal efforts emphasize preventive characteristics, namely creating policies before the occurrence of a criminal act, but in practice the handling of a crime occurs as a kind of disparity in treatment between the rights granted between the victim and the suspect in statutory regulations. ${ }^{2}$

According to Barda Nawawi Arief, policies or efforts to combat crime are in essence an integral part of efforts to protect society (social defense) and efforts to

\footnotetext{
${ }^{1}$ Soejono Soekanto, 2007, Sosiologi Suatu Pengantar, PT. Raja Grafindo Persada, Jakarta, p. 179 2Barda Nawawi Arief, 1991, Upaya Non Penal dalam Penanggulangan Kejahatan. Semarang, Faculty of Law, University Diponegoro, p. 1-2
} 
achieve social welfare. Therefore, it can be said that the ultimate goal or main goal of criminal politics is "protection of society to achieve social welfare". ${ }^{3}$

According to Muhammad Ikhsan, in criminal cases the victims of crime are actually the ones who suffer the most. In the settlement of criminal cases, often the law places too much emphasis on the rights of a suspect or defendant, while the rights of victims are neglected, one of which is the right to compensation, which is a right that requires someone who has acted detrimental to another to pay a certain amount of money or goods to someone. Those who have suffered losses, so that the losses that have occurred are deemed to have never occurred. Compensation is actually the realm of civil law, however in order to realize the simple, fast and low cost principle of justice, this compensation can be combined with a criminal examination. ${ }^{4}$

\section{Research Methods}

This type of research is normative legal research supported by empirical legal research, and uses a statutory approach as primary legal material.

\section{Result And Discussion}

\subsection{Factors Causing the Occurrence of Victims in the Crime of Persecution}

Talking about victims of crime in the beginning is of course individual or individual victims. This view is not wrong, because this is the case for crimes that commonly occur in society. For example murder, persecution, theft and so on. ${ }^{5}$

Based on the level of severity, behavior that deviates or violates the law consists of neurosis (mental disorder, mental disorders), psychosis and psychopathy (sociopathic symptoms) which include anti-social reactions, dissocial reactions, sexual deviations and addiction. The functions of the soul such as feelings, views, thoughts and life beliefs must be balanced so that harmony can be created which will keep a person away from feelings of doubt, doubt and avoid inner conflict (inner conflict) and anxiety. Mental health disorders will affect their attitudes and behavior such as feeling anxious, restless, low self-esteem, angry. If the person has a disturbed mind, he will often forget, there is no concentration and his intelligence will decline. Mental conditions are very decisive in this life, ${ }^{6}$

In the case of a criminal act of maltreatment, the factors that cause the occurrence of a criminal case of persecution are alcohol and psychological factors.

\footnotetext{
${ }^{3}$ Barda Nawawi Arief, 1986, Bunga Rampai Kebijakan Hukum Pidana, Citra Aditya Bakti, Bandung, p. 2

${ }^{4}$ Muhammad Ikhsan, 2012, Hukum Perlindungan Saksi Dalam Sistem Peradilan Pidana, Muhammadiyah University Press, Surakarta, p. 156

${ }^{5}$ Bambang Waluyo, 2014. Vikitimologi Perlindungan Saksi dan Korban, Sinar Grafika, Jakarta. p. 11

${ }^{6}$ Interview with the Head of Criminal Investigation Unit of the Sampang Police (AKP. Riki Donaire), on July $1,2020$.
} 
The alcohol factor (alcohol), it turns out that with the influence of alcoholic drinks, a person can take actions that without realizing whether his actions are considered right or wrong. The act acted out of his mind, as he was still under the influence of the alcoholic drink. A person who is influenced by alcoholic drinks will irritate him quickly, distract him from his attention to the environment and make the selfcontrol concerned aggressive and courageous. Psychological factors or psychologically here, a person is called normal if he can use his abilities and talents to the fullest and if not then he is called abnormal. This self-adjustment is closely related to normal and abnormal, which means that if a person succeeds in adjusting his behavior to his environment or if the person is able to adjust to the prevailing legal principles, the result is normal. ${ }^{7}$

\subsection{Implementation of Law Enforcement in the Merger of Indemnity Claims in the Crime of Persecution at the Sampang District Court}

Victims of crimes in the criminal justice system, according to Stanciu, quoted by Teguh Prasetyo, what is meant by victims in a broad sense are people who suffer the consequences of injustice. The appearance of a victim cannot be seen as the result of an illegal act because the law (legal) actually can also lead to injustice which then results in victims, such as victims due to legal procedures. The concept of crime and who is the victim of crime is the starting point for explaining the victim's legal position. ${ }^{8}$

According to Sudarto's opinion quoted by Suparman, it was stated that the determination of the injured person was based on civil law principles and the loss was caused by the actions of a person whom the criminal law calls "the maker" (Dader) of a criminal act. So in the case of compensation in criminal cases, it must be seen in terms of the "triad": offense (criminal act) - maker - victim. It must also be noted that the loss is material and immaterial. Compensation for material losses do not cause problems, it is not the case with immaterial losses, in the form of distress, anxiety, shame and so on. ${ }^{9}$

The dimension of compensation for the suffering of the victim if it is related to the restitution system, in the meaning of victimology, is related to the repair or restoration of physical, moral, property and rights of victims caused by criminal acts. The main character of this restitution is an indication of the responsibility of the maker for charges of restitutive action that are criminal in nature in criminal cases. ${ }^{10}$

\footnotetext{
7 Ibid.

${ }^{8}$ Siswanto Sunarso, 2014. Viktimologi Dalam Sistem Peradilan Pidana, Sinar Grafika, Jakarta, p. 42. ${ }^{9}$ Suparman, 2007, Kepentingan Korban Tindak Pidana dilihat dari Sudut Viktimologi, Law Magazine of FH-UI of XXII No. 260, July 2007, p. 50.

${ }^{10}$ Hendrojono, 2005, Kriminologi: Pengaruh Perubahan Masyarakat dan Hukum, PT. Raja Grafindo Persada, Jakarta, p. 173.
} 
The scope of law enforcement also includes restorative justice, which is a settlement carried out outside the criminal justice system by involving victims, perpetrators, victims' families and the community as well as parties with an interest in a criminal act that occurs to reach an agreement ${ }^{11}$. Restorative justice is considered a new way of thinking / paradigm in seeing a crime committed by a person. ${ }^{12}$

Legal protection for victims should be regulated explicitly in the Criminal Code. For example, in imposing a sentence against the perpetrator, it is also necessary to consider the losses suffered by the victim or the victim's family. So that the perpetrator could be given criminal compensation which might be more beneficial for the victim. ${ }^{13}$

Law enforcement is a process of activities or activities, one of which is carried out by law enforcers (POLRI / PPNS investigators, prosecutors and judges). To produce good law enforcement, the process of each stage in law enforcement must be carried out properly. Criminal law enforcement is an effort to uphold criminal law norms and all the values behind these norms (total enforcement), which is limited by the "area of no enforcement" through criminal procedural law or other special provisions, to maintain balance between the interests of the state, public interests and individual interests (full enforcement). So that legal development can be achieved in accordance with the aspirations so far. ${ }^{14}$

In the settlement of criminal cases, it is found that many victims are parties who are severely disadvantaged in a criminal act that should receive protection, the victim is placed as evidence that provides information, namely only as a witness, so that the possibility for victims of torture to gain freedom in fighting for their rights is small and should be get the same protection. ${ }^{15}$

\subsection{Barriers to Law Enforcement on Compilation of Compensation Suit in the Criminal Case of Persecution at the Sampang District Court}

Irianto Prijatna Utama, argued that for the people of Indonesia, weak law enforcement by the apparatus will determine the perception of the existence of a law. If law enforcement by the apparatus is weak, the community will perceive the law as non-existent as if they were in a jungle. On the other hand, if law

\footnotetext{
${ }^{11}$ Rully Trie Prasetyo, Umar Ma'ruf, Anis Mashdurohatun, 2017, Tindak Pidana Korporasi Dalam Perspektif Kebijakan Formulasi Hukum Pidana, Jurnal Hukum Khaira Ummah, Vol 12, No.4, Sultan Agung Islamic University Semarang, p. 727-741.

12 Ibid.

${ }^{13}$ Rena Yulia. 2010. Viktimologi Perlindungan Hukum Terhadap Korban Kejahatan. Graha Ilmu: Yogyakarta, p. 181,

${ }^{14}$ Ibid.

${ }^{15}$ Interview with the Intermediate Prosecutor at the Sampang District Attorney (Mr. Moch. Hasan, SH), on July 2, 2020
} 
enforcement by the apparatus is strong and carried out consistently, then society will perceive that the law exists and will submit. ${ }^{16}$

The obstacles that affect the community are not aware of the merger of cases, namely: 17

a. A long process in the mechanism for providing compensation to victims of crime.

b. Education level, from the results of the interview with the victim that the victim's education level only went to high school so that he does not know his rights as a victim of persecution can file a claim for compensation.

The obstacles that affect the community are not aware of the merger of cases, namely: 18

a. A long process in the mechanism for providing compensation to victims of crime.

b. Education level, from the results of the interview with the victim that the victim's education level only went to high school so that he does not know his rights as a victim of persecution can file a claim for compensation.

According to the results of the author's interview with the Chairman of the Sampang District Court, that every effort made is inseparable from the obstacles that are often encountered. Likewise, getting compensation is not easy because it has to go through a long process. This can be the main cause that becomes an obstacle for victims of criminal acts of persecution to get compensation as their right. 19

According to the author, studied with the theory of the legal system, the constraints on merging a lawsuit for compensation in a case of Criminal Persecution based on the provisions in the Criminal Procedure Code and the Judge's decision, it can be seen that the main problem is a criminal case, while a compensation suit is an additional (assesoir) with the main matter. So if the criminal case has permanent legal force, the compensation plaintiff cannot file a legal remedy.

\subsection{Efforts made by Law Enforcement to overcome obstacles in the Merger of Indemnity Claims in the Criminal Case of Persecution in the Sampang District Court in the future}

According to the explanation of the Intermediate Prosecutor to the Sampang District Attorney, that compensation for victims of criminal acts can basically be done in three ways, namely: ${ }^{20}$

16

Interview with the Head of the Sampang District Court (Mr. Irianto Prijatna Utama, SH., M.Hum), on July 3, 2020.

17 Ibid.

${ }^{18}$ Ibid.

19 Ibid.

20 Op.Cit. 
1. Through a Merger of Compensation Cases;

2. Through a Lawsuit against the Law, and

3. Through the Request for Restitution

Vereningings theorieen (combined theory). This theory is a reaction from the previous theory which cannot satisfactorily answer the nature of the number of convictions. According to the teachings of this theory, the legal basis for punishment lies in the crime itself, namely retaliation or torture, but besides that he also admits that the basis for formation is the goal of the law. ${ }^{21}$

One of the functions of law is to provide protection where the law is cultivated and needed by humans, precisely based on the products of human research, to create conditions that protect and promote human dignity and to enable humans to live a fair life according to their dignity. ${ }^{22}$

Law enforcement officers include the definition of law enforcement institutions and law enforcement officers (people). In a narrow sense, law enforcement officials who are involved in upholding the law, starting from witnesses, police, legal counsel, prosecutors, judges, and prison guard officers. Each related apparatus and apparatus also includes parties concerned with their duties or roles, namely related to reporting or complaint activities, investigations, investigations, prosecutions, proving, conviction and imposing sanctions, as well as efforts to re-correct (resocialization) of the convict. ${ }^{23}$

The mechanism for examining merger cases for compensation is based on the provisions of Article 101 of the Criminal Procedure Code using the mechanism regulated in the Civil Procedure Code. ${ }^{24}$

According to the authors, reviewed with the theory of legal protection, to overcome the obstacles in the Merger of Indemnity Claims in the Criminal Case of Persecution in the Sampang District Court in the future is with the courage and high moral responsibility of the Law Enforcers (Judges, Prosecutors and Police) in handling criminal cases of maltreatment by combining claims for compensation for victims of criminal acts of maltreatment.

\section{Closing}

Based on the explanation of the results of the study, it can be concluded as follows: The factors that cause the Crime of Persecution are: alcohol and psychological factors. Implementation of Law Enforcement on the Merger of Indemnity Claims in the Criminal Case of Persecution, it is known that the defendant has been tried with criminal sanctions, but does not include

\footnotetext{
21 Satochid Kartanegara, 1992, Hukum Pidana Bagian Satu, Balai Lektur Mahasiswa, Jakarta, 1992, p. 56.

22 Lili Rasjidi dan B. Arief Sidharta. 1994, Filsafat Hukum Madzab dan Refleksi. Remaja Rosida Karya, Bandung. p. 64.

${ }^{23}$ Muiz Thohir.1999, Lalu Lintas di Indonesia, Sinar Persada: Jakarta. p. 65

24 Op.Cit.
} 
compensation for victims of criminal acts of persecution. Obstacles or barriers to the implementation of law enforcement on the merger of indemnity suit in the case of the Crime of Persecution are: the legal factors themselves, especially laws; law enforcement factors, namely the parties who make and implement laws; actors of means or facilities that support law enforcement; community factors, namely the environment in which the law applies or is applied; cultural factors, namely as a result of creative work and taste based on human initiative in social life. Efforts made by Law Enforcement to overcome obstacles in the Merger of Indemnity Lawsuit in the future are: Through Merger of Compensation Cases, through Lawsuits for Unlawful Acts, and through Restitution Requests.

For Law Enforcement Officials (Judges, Attorneys, and Police) to always improve professionalism as community protection officers so that they always provide legal assistance and protection for victims of persecution, by combining compensation as demands and decisions, for the community to always learn and know about merging claims as well as decisions on criminal and civil cases for criminal cases of maltreatment that cause material harm to victims of persecution.

\section{References}

\section{Books:}

[1] Bambang Waluyo, 2014. Vikitimologi Perlindungan Saksi dan Korban, Sinar Grafika, Jakarta

[2] Barda Nawawi Arief, 1986, Bunga Rampai Kebijakan Hukum Pidana, Citra Aditya Bakti, Bandung

[3] Barda Nawawi Arief, 1991, Upaya Non Penal dalam Penanggulangan Kejahatan. Semarang, Faculty of Law, University Diponegoro

[4] Hendrojono, 2005, Kriminologi: Pengaruh Perubahan Masyarakat dan Hukum, PT. Raja Grafindo Persada, Jakarta

[5] Lili Rasjidi dan B. Arief Sidharta. 1994, Filsafat Hukum Madzab dan Refleksi. Remaja Rosida Karya, Bandung

[6] Muhammad Ikhsan, 2012, Hukum Perlindungan Saksi Dalam Sistem Peradilan Pidana, Muhammadiyah University Press, Surakarta

[7] Muiz Thohir.1999, Lalu Lintas di Indonesia, Sinar Persada: Jakarta

[8] Rena Yulia. 2010. Viktimologi Perlindungan Hukum Terhadap Korban Kejahatan. Graha Ilmu: Yogyakarta

[9] Satochid Kartanegara, 1992, Hukum Pidana Bagian Satu, Balai Lektur Mahasiswa, Jakarta, 1992

[10] Siswanto Sunarso, 2014. Viktimologi Dalam Sistem Peradilan Pidana, Sinar Grafika, Jakarta

[11] Soejono Soekanto, 2007, Sosiologi Suatu Pengantar, PT. Raja Grafindo Persada, Jakarta

[12] Suparman, 2007, Kepentingan Korban Tindak Pidana dilihat dari Sudut Viktimologi, Law Magazine of FH-UI of-XXII No. 260, July 2007 


\section{Journal:}

[1] Rully Trie Prasetyo, Umar Ma'ruf, Anis Mashdurohatun, 2017, Tindak Pidana Korporasi Dalam Perspektif Kebijakan Formulasi Hukum Pidana, Jurnal Hukum Khaira Ummah, Vol 12, No.4, Sultan Agung Islamic University Semarang

\section{Interview:}

[1] Interview with the Head of Criminal Investigation Unit of the Sampang Police (AKP. Riki Donaire), on July 1, 2020.

[2] Interview with the Head of the Sampang District Court (Mr. Irianto Prijatna Utama, SH., M.Hum), on July 3, 2020.

[3] Interview with the Intermediate Prosecutor at the Sampang District Attorney (Mr. Moch. Hasan, SH), on July 2, 2020 